\title{
Heavy mineral as a tool to refine the stratigraphy of kaolin deposits in the Rio Capim Area, Northern Brazil
}

\author{
ANA M. GÓES ${ }^{1}$, DILCE F. ROSSETTI ${ }^{2}$ and ANDERSON C. MENDES ${ }^{3}$ \\ ${ }^{1}$ Instituto de Geociências, Universidade de São Paulo, Rua do Lago 562, 05508-080 São Paulo, SP, Brasil \\ ${ }^{2}$ Centro de Observação da Terra, Instituto Nacional de Pesquisas Espaciais, Rua dos Astronautas 1758, \\ Caixa Postal 515, 12245-970 São José dos Campos, SP, Brasil \\ ${ }^{3}$ Centro de Geociências, Universidade Federal do Pará, Rua Augusto Côrrea, 01, \\ Caixa Postal 1611, 66075-110 Belém, PA, Brasil \\ Manuscript received on July 11, 2006; accepted for publication on October 31, 2006; \\ presented by ALCIDES N. SIAL
}

\begin{abstract}
Studies of heavy minerals in kaolin deposits from the Ipixuna Formation in the Rio Capim area (Northern Brazil) showed a mature to super mature assemblage dominated by zircon and tourmaline, and subordinately rutile, kyanite and staurolite. These minerals do not change much throughout the whole section; however, each kaolin unit displays a particular signature, defined by differences in the proportions of the whole assemblage of heavy minerals, as well as of their textural characteristics. This work revealed that the lower and upper kaolin units can be definitely considered as distinct depositional sequences. A higher proportion of opaque minerals and higher zircon values characterize the lower unit. The higher volumes of anhedric, rounded to sub-rounded grains of zircon and tourmaline in the upper unit suggests that this includes grains that were undergone to a higher degree of reworking. The increased volume of unaltered staurolite and kyanite in the upper unit leads to conclude that, even considering sediment reworking, a distinct source must be invoked. The results also show that the characteristics of the heavy mineral assemblage from the intermediate unit are comparable with those from the upper unit, which suggests they might record a same stratigraphic sequence.
\end{abstract}

Key words: heavy minerals, kaolin deposits, Ipixuna Formation, Early Cretaceous, Cametá Sub-Basin.

\section{INTRODUCTION}

The Ipixuna Formation corresponds to a thin (usually $40 \mathrm{~m}$ thick), typically kaolinitized stratigraphic unit of the Itapecuru Group, preserved between Albian and Neogene deposits along the Rio Capim area in the northeast of the State of Pará (Fig. 1). Because of its valuable kaolin reserve that has fed the international market of paper production in these last decades, this unit has been increasingly studied on several aspects. Given the sedimentary nature of the kaolin deposits, many sedimentological studies have been carried out lately in order to

Correspondence to: Dr. Ana Maria Góes

E-mail: goes@igc.usp.br better provide the framework to understand its mode of deposition and the stratigraphic context, ultimately contributing to provide a genetic interpretation for this kaolin occurrence. As a result of these studies, two types of kaolin have been recognized, consisting of a lower soft kaolin unit, and an upper hard kaolin unit, called "semiflint", a term defined for a flint-like fire clay consisting of endured kaolinite with no plasticity when grounded up.

An important aspect that has been reinforced in recent publications is that these units, rather than been gradational in nature and closely related to differentiation during progressive weathering, as previously proposed (e.g., Truckenbrodt et al. 1991, Kotschoubey et al. 1996, 


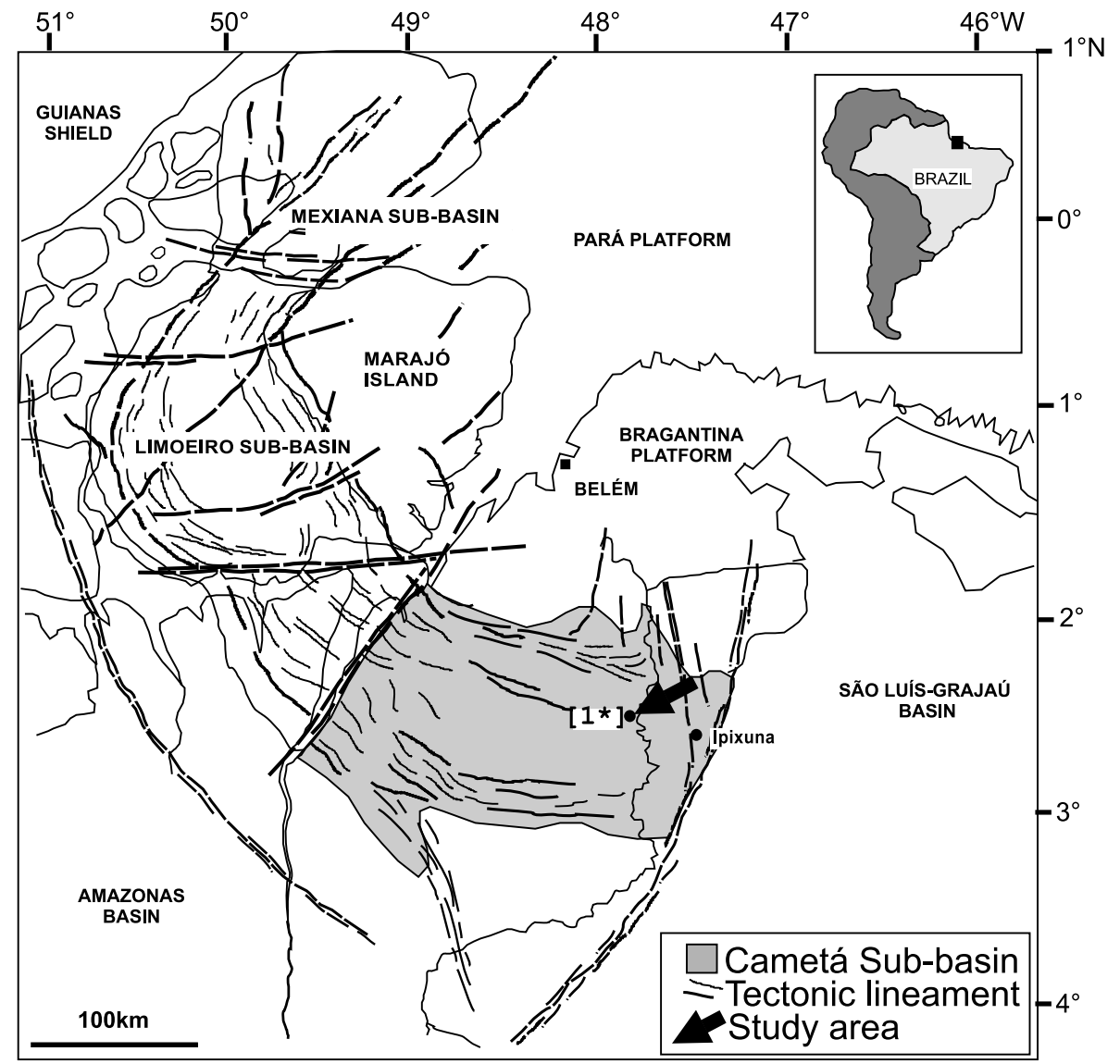

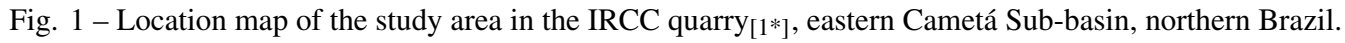

1999, Costa and Moraes 1998), are in sharp contact and probably have a distinct mode of formation. In fact, this contact is complex, and includes a series of prominent discontinuity surfaces, some associated with a variety of brittle and ductile soft sediment deformation structures attributed to syn-sedimentary seismic activity (Rossetti and Santos Jr 2003). In addition, field mapping has led to the identification of three stratigraphic units, informally named as lower, intermediate, and upper kaolin units (Santos Jr and Rossetti 2003, Rossetti and Santos Jr 2003, Rossetti 2004).

This paper aims to characterize the assemblage of heavy minerals of the kaolin units of the Ipixuna Formation in a quarry of the Rio Capim area in order to provide new elements to better evaluate if they can, in fact, be part of different stratigraphic units. Analysis of dense minerals is widely used as a tool for stratigraphic correlation in sandstone dominated sequences lacking biostratigraphic control (Weissbrod and Nachmias 1986, Morton 1991, Morton and Hurst 1995, Mange-Rajetzky 1995, Smaler and Laird 1995, Morton et al. 1996, Morton and Grant 1998, Hermann and Polozek 1999, Svendsen and Hartley 2002, Mange et al. 2003). Other studies focusing sedimentary basins in northern and northeastern Brazil have shown that this type of approach using heavy minerals might be of a valuable tool for helping to establish the stratigraphic framework in areas where the sedimentary units display similar lithofaciological composition (Rossetti et al. 1989, Sousa et al. 2000, Nascimento and Góes 2005, Truckenbrodt et al. 2005). Additionally, although facies analysis has shown that the Rio Capim kaolin might include well stratified sandstones (Santos Jr and Rossetti 2003, Rossetti and Santos Jr 2003, 2006, Rossetti 2004), it appears that massive deposits composed entirely of clay minerals are dominant. This is particularly the case for the semi-flint unit, which has been attributed 
to deposition in low energy, probably lacustrine depositional settings with prevalence of mud settling from suspensions (ref. Kotschoubey et al. 1996). Ongoing detailed petrographic and scanning electronic microscopic studies have demonstrated that the massive, "muddy" kaolin might, in fact, include a variety of lithologies that range from mudstones to conglomerates. Therefore, the apparent muddy nature of the semi flint kaolin might be due, at least in part, to post depositional modification of coarser-grained lithologies (Rossetti and Santos Jr 2006). The present study conforms to this hypothesis, as kaolin deposits displaying massive nature revealed to contain an abundant volume of heavy minerals in the sand grain sizes. Characterization of heavy mineral assemblage, thus, might provide new elements to better discuss the depositional facies of the kaolin units in the Rio Capim area.

\section{GEOLOGICAL FRAMEWORK}

The Cametá Sub-basin, together with the Limoeiro, Mexiana and Mocajuba Sub-basins, constitutes the Marajó Graben System, located at the mouth of the Amazon River, northern Brazil. These structures were formed by NW-SE and NNW-SSE normal faults and NE-SW and ENE-WSW strike-slip faults during the opening of the Equatorial South Atlantic Ocean (R.P. Azevedo, unpublished data, M.V.G. Galvão, unpublished data, J.M. Villegas, unpublished data, Costa et al. 2002).

The Cametá Sub-basin is up to $10 \mathrm{~km}$ thick, and includes Cretaceous and Cenozoic deposits (Fig. 2), which are mostly known from sub-surface data. The Cretaceous succession includes the Breves Formation (AptianCenomanian) and the Limoeiro Formation (Late Cretaceous), considered as fluvial and marine transitional in origin. The Tertiary and Quaternary deposits include the Marajó Formation (Paleocene-Eocene) and the Tucunaré Formation (Pleistocene), both originated within marine to transitional environments (Brandão and Feijó 1994, Milani and Thomaz Filho 2000).

Exposures of Cretaceous rocks in the Cametá Subbasin are only found in the eastern margin of the basin, where Albian/Cenomanian deposits are cut by a kaolinitized Upper Cretaceous unit referred as the Ipixuna Formation, which is the subject of this paper. This unit is particularly well exposed in the Rio Capim Kaolin area,

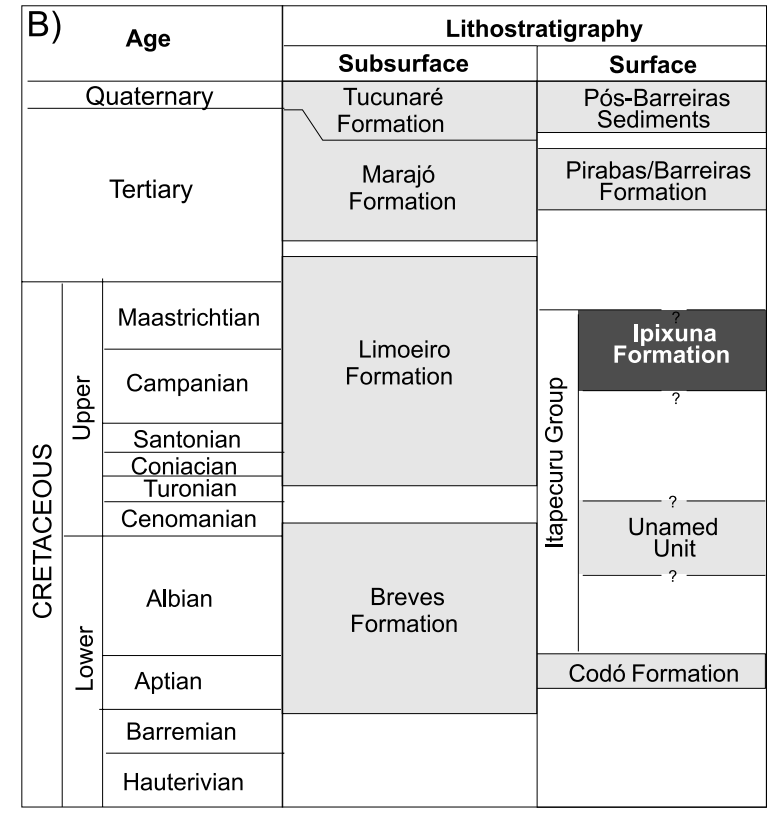

Fig. 2 - Lithostratigraphy of the Cametá Sub-basin, where studied kaolin deposits, represented by the Ipixuna Formation, are inserted.

where it shows thickness of nearly $40 \mathrm{~m}$ and consists of kaolinitized mudstones and sandstones. Previously regarded as a single stratigraphic unit, the Ipixuna Formation has been more recently subdivided into three units. Facies analysis of the lower unit, corresponding to the soft and commercially exploited kaolin, revealed a variety of well structured deposits formed by tidal currents and waves in settings including tidal-influenced fluvial channel, tidal channel, tidal flat/mangrove, and tidal sand bar/tidal sandy flat, typifying a tide-dominated estuarine system (Santos Jr and Rossetti 2003). A marine influence is attested by the nature of the sedimentary structures attributed to tidal processes (i.e., reactivation surfaces, foresets with bi-directional azimuths, mud couplets), as well as by the ichnological assemblage consisting of Diplocraterion, Planolites, Thalassinoides, Teichichinus, Taenidium, Skolithos, Chondrites? and Cylindrichnus (Santos Jr and Rossetti 2003). The top of the soft kaolin is cut by a discontinuity surface locally marked by several vertical fractures that disappear into underlying undeformed deposits, and which have been attributed to syn-sedimentary seismic activity (Rossetti and Santos Jr 2003).

The intermediate unit is only locally well devel- 
oped, representing a package up to $3 \mathrm{~m}$ thick of well stratified, heterolithic mudstone and very fine-grained sandstone. These are sharply interbedded with heterolithic deposits displaying a variety of soft sediment deformation structures, mostly convolute folds and pillow-like structures. The unit is overlain by a discontinuity surface with lateritic paleosol or a lag of ferruginous concretions and mudstone clasts. Deposits from the intermediate unit have been attributed to deposition in low energy estuarine areas, episodically affected by soft sediment deformation related to syn-sedimentary seismic activity and large-scale mass failure trough debris flows and slumps (Rossetti and Santos Jr 2003).

The upper unit, corresponding to the semi flint kaolin, has an apparent structureless muddy nature, mostly due to a strong pedogenesis throughout, revealed by an abundance of root marks, highlighted by iron cementation. However, detailed sedimentologic investigation of freshly exposed and thicker sections revealed features resembling primary sedimentary features that record either distributary channels and mouth bar, or tidal inlet and tidal delta areas possibly associated with deltaic or wave-dominated estuarine settings, respectively (Rossetti and Santos Jr 2006). Based on this information, these authors suggested that the apparent muddy nature of the semi flint kaolin might be due to post depositional modification of sandstones and conglomerates displaying grain sizes with either lithic or mud composition. They also proposed that the grains might have been derived, at least in part, from erosion of the underlying kaolinitized soft kaolin unit during the episode of exposure that led to the formation of the unconformity with lateritic paleosol in its top. In addition, the upper kaolin unit contains undulatory surfaces mantled by thin (2-4 cm thick) medium- to coarse-grained sandstones essentially composed of well-sorted and well-rounded quartz grains that might have been derived from a distinct (marine?) source, associated to a wave ravinement (Rossetti and Santos Jr 2006).

\section{MATERIALS AND METHODS}

This study was based on the analysis of 47 samples of kaolinitized sandstones derived from two profiles at the IRCC quarry. Soft samples were hand disaggregated, while consolidated samples stayed soaked in dissolved sodium pyrophosphate for several days. The disaggregated material was wet-sieved to eliminate the grain sizes under $0.062 \mathrm{~mm}$. The sand grain sizes were dry sieved. Heavy minerals were concentrated from the grains sizes between 63 to $125 \mathrm{~mm}$ (very fine-grained sand) using bromoform (cf. Morton 1985, Mange and Maurer 1992, Morton and Hallsworth 1999). The concentrates were mounted on glass-slides with the help of araldite glue and examined under a petrographic microscope for species descriptions, with counting of 100 grains per slide. The percentage of transparent and non-transparent minerals was also based on the counting of 100 grains per slide. The degree of mineralogical maturity (Hubert 1962) was obtained using the sum of the percentages of zircon, tourmaline and rutile (ZTR).

The main morphological characteristics of 100 grains per sample of the most frequent and abundant minerals, consisting of zircon and tourmaline, were described in more detail. This procedure allowed comparisons of all samples and the establishment of independent criteria to help differentiating and better characterizing the degree of transport and diagenetic modification of the deposits in the stratigraphic units. Degree of chemical alteration was additionally evaluated under the electronic scanning microscope (SEM) with basis on circa 10 grains of tourmaline. Samples were mounted in a double-face tape, and coated with $\mathrm{Au}$, and analyzed under a LEO-1450VP microscope of the Museu Paraense Emílio Goeldi.

\section{CHARACTERIZATION OF THE HEAVY MINERAL ASSEMBLAGE}

The studied kaolin deposits display a mature to supermature assemblage of heavy minerals, represented dominantly by zircon and tourmaline, and secondarily rutile, kyanite, staurolite and topaz, with traces of anatase, amphibole, garnet, monazite, andalusite, dumortierite and brookite. Despite the overall stable nature, the proportion among minerals is highly variable from one stratigraphic unit to another, allowing their differentiation. The proportions of altered/unaltered and opaque/transparent minerals, as well as the roundness, revealed to be valuable parameters to further help distinguishing these units (Tables I-II, Figs. 3-4). 
TABLE I

Percent composition of heavy minerals in the 63-250 micron size fraction from kaolin units in IRCC quarry. TR $=$ trace $(<1 \%)$, ZTR $=$ Zircon + Tourmaline + Rutile, Tra = Transparent, $Z=$ Zircon, $T=$ Tourmaline, Ky = kyanite, $\mathrm{St}=$ staurolite, $\mathrm{R}=$ Rutile, Top = Topaz, An = Anatasio, $\mathrm{G}=$ Garnet, $\mathrm{M}=$ Monazite, Am = Amphibole, And = Andalusite, $\mathrm{Du}=$ Dumortierite, $\mathrm{Ep}=$ Epidote and $\mathrm{B}=$ Brookite.

\begin{tabular}{|c|c|c|c|c|c|c|c|c|c|c|c|c|c|c|c|c|c|}
\hline \multirow{6}{*}{$\begin{array}{l}\mathrm{U} \\
\mathrm{P}\end{array}$} & UNIT & SAMPLE & $\mathrm{Z}$ & $\mathrm{T}$ & $\mathrm{Ky}$ & St & $\mathrm{R}$ & Top & $\mathrm{An}$ & $\mathrm{G}$ & $\mathrm{M}$ & $\mathrm{Am}$ & And & $\mathrm{Du}$ & Ep & B & ZTR \\
\hline & \multirow{5}{*}{$\begin{array}{c}\text { QUARTZ } \\
\text { SAND } \\
\text { LAYER }\end{array}$} & A15 & 21 & 19 & 18 & 34 & 7 & 1 & & & & & & & & & 47 \\
\hline & & $\mathrm{A} 01$ & 26 & 32 & 17 & 18 & 7 & & & & & & & & & & 65 \\
\hline & & A04 & 50 & 11 & 9 & 22 & 8 & & & & & & & & & & 69 \\
\hline & & A02 & 42 & 25 & 8 & 17 & 8 & & TR & & & & & & & & 76 \\
\hline & & MEAN & 35 & 22 & 13 & 23 & 7 & & TR & & & & & & & & 64 \\
\hline \multirow{4}{*}{$\begin{array}{l}P \\
E \\
R\end{array}$} & \multirow{14}{*}{ KAOLIN } & A16 & 78 & 14 & 2 & 2 & 3 & 1 & TR & & & & & & & & 95 \\
\hline & & A22 & 68 & 17 & 4 & 2 & 8 & 1 & TR & & & & & & & & 93 \\
\hline & & A14 & 72 & 17 & 3 & 1 & 5 & 2 & TR & & TR & & & & & & 94 \\
\hline & & A03 & 69 & 14 & 3 & 2 & 9 & 1 & 2 & & TR & & & & & & 92 \\
\hline K & & A13 & 66 & 19 & 1 & 3 & 6 & 5 & TR & TR & & & & & & & 91 \\
\hline A & & A5A & 66 & 24 & 1 & 1 & 6 & 2 & TR & TR & & & & TR & & & 96 \\
\hline $\mathrm{O}$ & & A5B & 74 & 19 & 1 & 2 & 3 & 1 & TR & & & & & & & & 96 \\
\hline $\mathrm{L}$ & & A18 & 73 & 19 & 1 & 1 & 4 & 1 & 1 & & TR & & & TR & & & 96 \\
\hline I & & E122 & 63 & 25 & 3 & 2 & 5 & 2 & TR & & & & & & & & 93 \\
\hline $\mathrm{N}$ & & E121 & 75 & 16 & 1 & 2 & 5 & 1 & TR & & & & & & & & 96 \\
\hline & & E120 & 78 & 13 & 1 & 2 & 5 & 1 & TR & TR & & & TR & & & & 96 \\
\hline & & E119 & 79 & 12 & 1 & 2 & 5 & 1 & TR & & TR & & & & & & 96 \\
\hline & & E118 & 76 & 15 & 1 & 2 & 4 & 1 & 1 & TR & & & TR & & & & 95 \\
\hline & & MEAN & 72 & 17 & 2 & 2 & 5 & 2 & & & & & & & & & 94 \\
\hline \multirow{3}{*}{\multicolumn{2}{|c|}{ INTERM }} & E117 & 74 & 14 & 2 & 1 & $\overline{66}$ & 3 & 1 & & & & & & $\begin{array}{l}\text { TR } \\
\end{array}$ & & 94 \\
\hline & & E116 & 74 & 16 & 1 & & 7 & & 2 & & & & & & & & 97 \\
\hline & & E115 & 61 & 30 & 2 & 1 & 4 & 1 & 1 & & & & & & & & 95 \\
\hline \multirow{2}{*}{\multicolumn{2}{|c|}{ KAOLIN }} & E114 & 73 & 21 & 1 & 1 & 3 & 1 & $\mathrm{TR}$ & & & & & & & $\mathrm{TR}$ & 97 \\
\hline & & MEAN & 68 & 22 & 2 & 1 & 5 & 1 & 1 & & & & & & & & 96 \\
\hline \multirow{12}{*}{\multicolumn{2}{|c|}{$\begin{array}{l}\text { LOWER } \\
\text { KAOLIN }\end{array}$}} & A17 & 84 & 10 & 1 & 2 & 2 & 1 & TR & TR & TR & & & & & & 96 \\
\hline & & A20 & 85 & 10 & 1 & 1 & 2 & 1 & $\mathrm{TR}$ & & & TR & & & & & 97 \\
\hline & & A19 & 87 & 6 & 2 & 1 & 2 & 1 & 1 & & TR & TR & & & & & 95 \\
\hline & & A08 & 85 & 9 & 1 & 1 & 3 & 1 & TR & TR & TR & TR & & & & & 97 \\
\hline & & A07 & 86 & 6 & 2 & 3 & 2 & 1 & TR & TR & & & & & & & 94 \\
\hline & & A06 & 88 & 3 & 1 & 2 & 5 & 1 & & & $\mathrm{TR}$ & TR & & & & & 96 \\
\hline & & A09 & 85 & 9 & 1 & 1 & 2 & 1 & 1 & & TR & TR & & & & & 96 \\
\hline & & E112 & 82 & 8 & 2 & 1 & 6 & 1 & $\mathrm{TR}$ & & $\mathrm{TR}$ & & & & & & 96 \\
\hline & & E111 & 86 & 8 & 1 & 1 & 2 & 1 & 1 & & & & & & & & 96 \\
\hline & & E110 & 84 & 9 & 1 & 3 & 2 & 1 & & & & & & & & & 95 \\
\hline & & E109 & 83 & 9 & 1 & 1 & 4 & 1 & 1 & & TR & & TR & & & & 96 \\
\hline & & E108 & 83 & 8 & 2 & 1 & 5 & 1 & TR & & TR & & & & & & 96 \\
\hline
\end{tabular}


TABLE I (continuation)

\begin{tabular}{c|c|c|c|c|c|c|c|c|c|c|c|c|c|c|c|c}
\hline UNIT & SAMPLE & Z & T & Ky & St & R & Top & An & G & M & Am & And & Du & Ep & B & ZTR \\
\hline \multirow{6}{*}{} & E107 & 82 & 9 & 1 & 1 & 6 & 1 & & & & & & & & & 97 \\
\hline & E106 & 87 & 6 & 1 & 1 & 4 & 1 & TR & & & & & & & & 97 \\
\hline & E105 & 85 & 7 & 3 & 1 & 3 & 1 & TR & & & & & & & & 95 \\
\hline & E104 & 80 & 7 & 2 & 4 & 6 & 1 & TR & & & & & & & & 93 \\
\hline & E103 & 88 & 3 & 3 & 1 & 4 & 1 & TR & TR & TR & & & & & & 95 \\
\hline & E102 & 93 & 2 & 2 & 1 & 1 & 1 & TR & & TR & & & & & & 96 \\
\hline & E101 & 85 & 4 & 3 & 1 & 6 & 1 & TR & TR & TR & & TR & & & & 95 \\
\hline & E100 & 88 & 6 & 1 & 1 & 3 & 1 & TR & & & & & & & & 97 \\
\hline & E99 & 89 & 1 & 2 & 1 & 6 & 1 & TR & TR & TR & & & & & & 96 \\
\hline & E98 & 95 & 1 & 1 & 1 & 1 & 1 & TR & & TR & & & & & & 97 \\
\hline & E97 & 94 & 2 & 1 & & 2 & & 1 & & TR & & & & & & 98 \\
\hline & E96 & 83 & 4 & 4 & 4 & 4 & 1 & & & & & & & & & 91 \\
\hline & E95 & 86 & 5 & 2 & 2 & 4 & 1 & TR & & & & & & & & 95 \\
\hline & E124 & 85 & 5 & 5 & 1 & 3 & 1 & TR & & TR & & & & & & 93 \\
\hline
\end{tabular}

\section{LOWER KAOLIN UNIT}

This unit is dominated by opaque ( $86 \%$ ), with only $14 \%$ of heavy minerals. The transparent minerals mostly include zircon $(86 \%)$, tourmaline $(6 \%)$, rutile $(4 \%)$, kyanite $(2 \%)$, staurolite $(1 \%)$, and topaz $(1 \%)$, with traces of garnet, monazite, andalusite, hornblende and anatase. The ZTR sum is $96 \%$. Zircon grains are dominantly colorless and, more rarely, yellow and pink. The grains are anhedric angular to sub-angular (43\% Fig. 5A) and euhedric to sub-euhedric (34\% Fig. 5B), as well as anhedric rounded to sub-rounded (23\%). This heavy mineral species might display either conchoidal or radial fractures, but it typically does not show any evidence for alteration. Tourmaline grains are brown to greenish brown, and very rarely, brownish yellow and blue. The grains are anhedric angular to sub-angular (70\%) and similar proportions of euhedric to sub-euhedric (14\% Fig. 5C). They are mostly partly altered (51\% Fig. 5D), with similar proportions of unaltered (20\%) and very altered (29\%) grains. Alteration occurs as dissolution etching (cf. Mahaney 2002) that is either chaotically arranged or aligned perpendicular to c-axis (Fig. 5D). Sub-parallel linear and conchoidal fractures are common. Kyanite is typically colorless, dominantly prismatic and mostly shows dissolution etching (Fig. 5E) and inclusions. Staurolite is brownish to reddish yellow, dominantly irregular shaped, angular and, more rarely, prismatic. This mineral shows frequent and abundant mamelonar dissolution features (Fig. 5E). In addition, dissolution lines displaying lenticular shapes are also common in some grains. Rutile is, in general, dark red to dark yellow, anhedric, and either angular or rounded, with no evidence for dissolution. Topaz is colorless, anhedric, angular and also without alteration features.

\section{INTERMEDIATE KAOLIN UNIT}

This unit shows an increase in the percentage of transparent minerals relative to the lower kaolin unit, with an average of $30 \%$ of the total heavy mineral assemblage. The transparent minerals mostly include zircon $(68 \%)$, tourmaline $(22 \%)$, rutile $(5 \%)$, kyanite $(2 \%)$, and staurolite, topaz and anatase ( $1 \%$ each one), with traces of epidote, and brookite. The ZTR sum is $96 \%$, thus representing the same percentage relative to the lower kaolin unit. Zircon grains display colors that are similar to the lower unit, but with an increase in anhedric rounded to sub-rounded grains (50\%), with a consequent decrease in euhedric to sub-euhedric (24\%) and anhedric rounded to sub-rounded $(20 \%)$. The tourmaline is mostly altered $(54 \%)$, with very altered $(26 \%)$ and unaltered (20\%) grains occurring subordinately. The grains are anhedric angular to sub-angular (51\%) with rounded to subrounded (46\%) and euhedric to sub-euhedric (3\%) grains 
TABLE II

Morphologies and alteration of tourmaline and morphologies of zircon grains from kaolin units in IRCC quarry. * = insufficient grains, T1 = euhedric to sub-euhedric tourmaline, $\mathbf{T} 2=$ anhedric angular to sub-angular tourmaline, $\mathbf{T 3}=$ anhedric rounded to sub-rounded tourmaline, $\mathrm{Z1}=$ euhedric to sub-euhedric zircon, $\mathrm{Z2}=$ anhedric angular to sub-angular zircon, $\mathrm{Z3}=$ anhedric rounded to sub-rounded zircon, $\mathrm{TA}=$ unaltered tourmaline, $\mathrm{TB}=$ altered tourmaline and $\mathrm{TC}=$ very altered tourmaline.

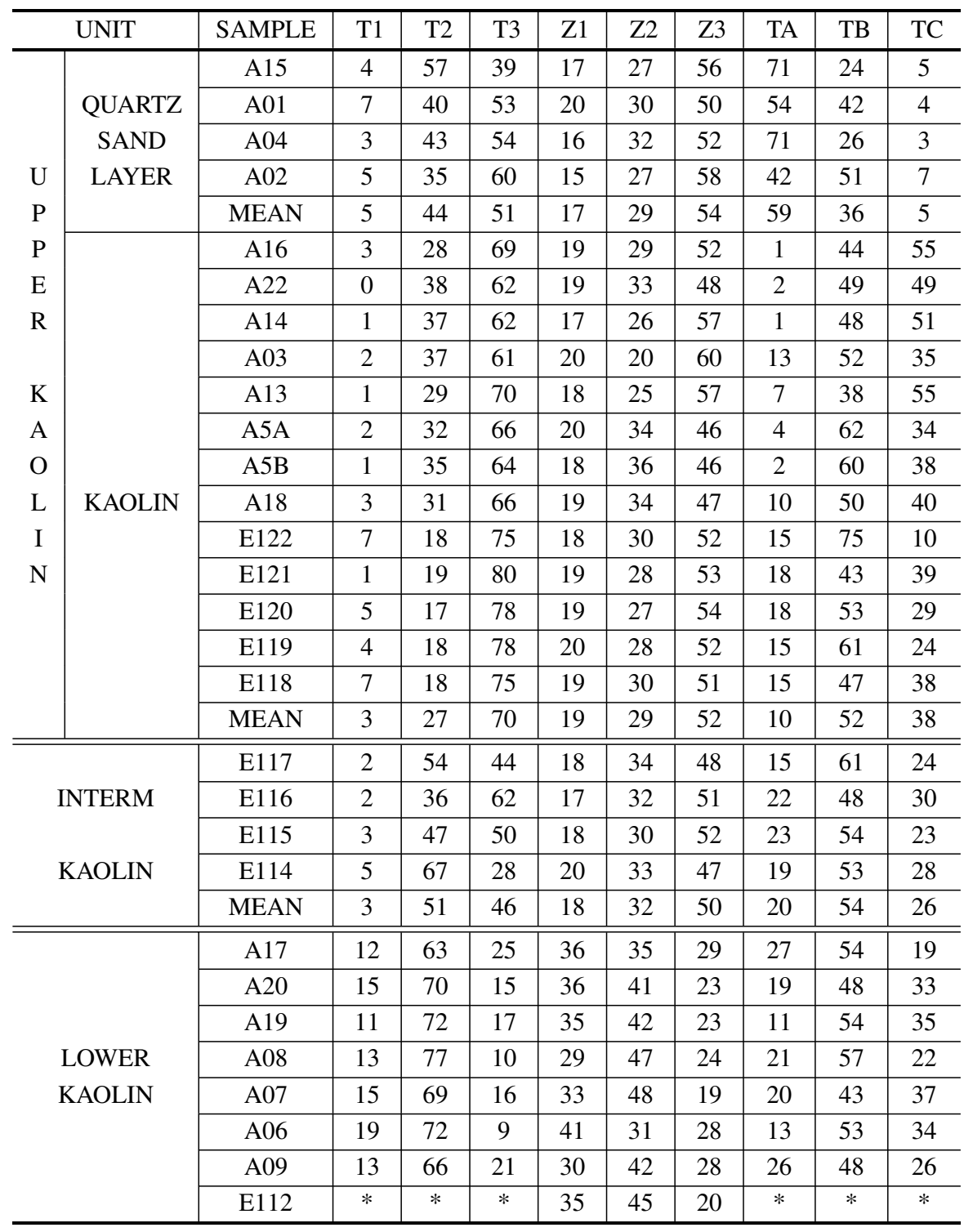


TABLE II (continuation)

\begin{tabular}{|c|c|c|c|c|c|c|c|c|c|c|}
\hline UNIT & SAMPLE & $\mathrm{T} 1$ & $\mathrm{~T} 2$ & T3 & $\mathrm{Z1}$ & $\overline{\mathrm{Z} 2}$ & $\mathrm{Z3}$ & TA & TB & TC \\
\hline \multirow{19}{*}{$\begin{array}{l}\text { LOWER } \\
\text { KAOLIN }\end{array}$} & E111 & $*$ & $*$ & $*$ & 33 & 46 & 21 & $*$ & $*$ & $*$ \\
\hline & E110 & $*$ & $*$ & $*$ & 31 & 43 & 26 & $*$ & $*$ & $*$ \\
\hline & E109 & $*$ & $*$ & $*$ & 32 & 42 & 26 & $*$ & $*$ & $*$ \\
\hline & E108 & $*$ & $*$ & $*$ & 36 & 41 & 23 & $*$ & $*$ & $*$ \\
\hline & E107 & $*$ & $*$ & $*$ & 32 & 43 & 25 & $*$ & $*$ & $*$ \\
\hline & E106 & $*$ & $*$ & $*$ & 34 & 46 & 20 & $*$ & $*$ & $*$ \\
\hline & E105 & $*$ & $*$ & $*$ & 34 & 45 & 21 & $*$ & $*$ & $*$ \\
\hline & E104 & $*$ & $*$ & $*$ & 33 & 45 & 22 & $*$ & $*$ & $*$ \\
\hline & E103 & $*$ & $*$ & $*$ & 30 & 46 & 24 & $*$ & $*$ & $*$ \\
\hline & E102 & $*$ & $*$ & $*$ & 31 & 44 & 25 & $*$ & $*$ & $*$ \\
\hline & E101 & $*$ & $*$ & $*$ & 36 & 45 & 19 & $*$ & $*$ & $*$ \\
\hline & E100 & * & $*$ & $*$ & 33 & 46 & 21 & $*$ & $*$ & $*$ \\
\hline & E99 & $*$ & $*$ & $*$ & 34 & 47 & 19 & $*$ & $*$ & $*$ \\
\hline & E98 & * & $*$ & $*$ & 32 & 44 & 24 & $*$ & $*$ & $*$ \\
\hline & E97 & $*$ & $*$ & $*$ & 36 & 45 & 19 & $*$ & $*$ & $*$ \\
\hline & E96 & $*$ & $*$ & $*$ & 33 & 44 & 23 & $*$ & $*$ & $*$ \\
\hline & E95 & $*$ & $*$ & $*$ & 34 & 42 & 24 & $*$ & $*$ & $*$ \\
\hline & E124 & $*$ & $*$ & $*$ & 39 & 33 & 28 & $*$ & $*$ & $*$ \\
\hline & MEAN & 14 & 70 & 16 & 34 & 43 & 23 & 20 & 51 & 29 \\
\hline
\end{tabular}

occurring subordinately. Alteration patterns are similar than in the upper unit. These data are very different than in the lower unit, with decrease of zircon proportion and increase of tourmaline proportion.

\section{UPPER KAOLIN UNIT}

Considering the possibility of distinct sources, as previously mentioned, the following description of heavy minerals from the bulk of the upper kaolin unit must be presented in separate from that of the thin layers of quartz sandstones related to the surfaces attributed to wave ravinement. Hence, the bulk of the kaolin in this unit displays an increased percentage of transparent minerals relative to the underlying kaolin units, with an average of $32 \%$ of the total heavy mineral assemblage. The transparent minerals mostly include zircon (72\%), tourmaline (17\%), rutile (5\%) and kyanite, staurolite and topaz ( $2 \%$ each one), with traces of garnet, monazite, andalusite, anatase and dumortierite. The ZTR sum of 94\% approaches the values obtained for the intermediate unit. Zircon displays colors that are similar to the underlying units, but the grains are dominantly anhedric rounded to sub-rounded (52\% Fig. 6A), with only $29 \%$ of angular to sub-angular grains and $19 \%$ of euhedric to sub-euhedric grains. As occurs with the intermediate unit, all minerals present in this unit display morphological features similar to the lower kaolin unit. The tourmaline grains are anhedric rounded to sub-rounded (70\% Fig. 6B) and angular to sub-angular (27\%) and very rarely euhedric to sub-euhedric (3\%). Tourmaline is mostly very altered and altered (90\% Fig. 6C), with unaltered (10\%) grains occurring subordinately. Subparallel linear and conchoidal fractures are common. Staurolite and kyanite occur as altered (Fig. 6D-E) and unaltered grains. Rutile and topaz display colors and forms that are similar to the underlying units.

Despite the overall similarity in heavy mineral assemblage, the quartz sand layers show a slight increase (i.e., 35\%) in the total amount of transparent minerals, with a marked increase in the volume of staurolite (23\%) and kyanite (13\%), and consequently decrease in zircon $(35 \%)$ relative to all other kaolin deposits of the study area. Other minerals present are rutile (7\%) and traces of anatase and topaz. The ZTR sum is also much lower, i.e., 64. Zircon is dominantly anhedric rounded to subrounded (54\%), with $29 \%$ of angular to sub-angular and 


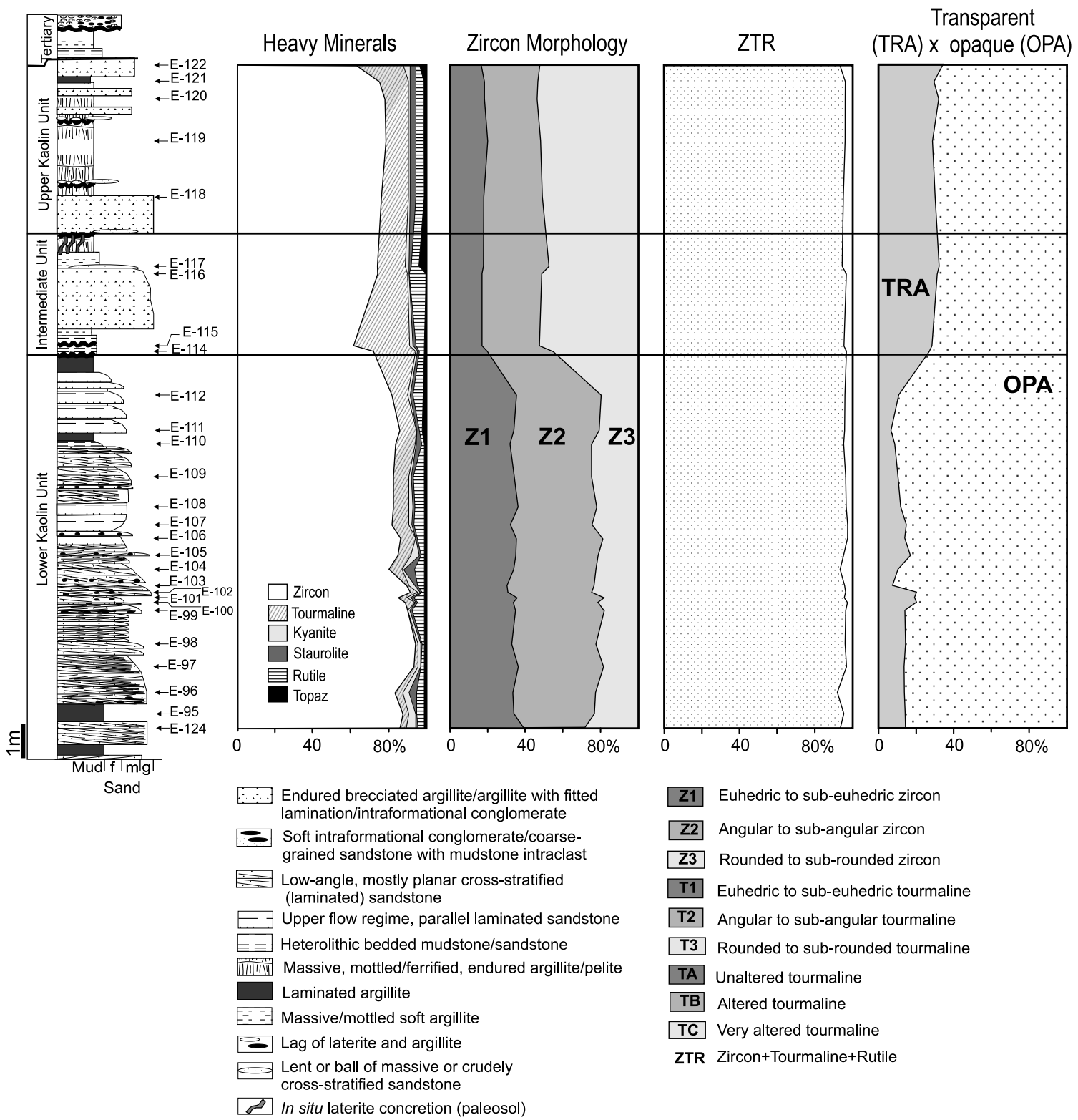

Fig. 3 - Measured lithostratigraphic profile 1 of the IRCC quarry, with frequencies of main heavy minerals and of their textures.

$17 \%$ of euhedric to sub-euhedric. Tourmaline is mostly unaltered $(59 \%)$ and altered $(36 \%)$, with very altered grains $(5 \%)$ occurring subordinately. The grains are anhedric rounded to sub-rounded (51\%), angular to subangular (44\%), and very rarely euhedric to sub-euhedric (5\%). Despite the fact that the quartz sand layers display morphotypes that are similar to the remaining of this unit, there is a promptly noticeable increase in the volume of unaltered staurolite, tourmaline and kyanite (Fig. 6F) relatively to the other kaolin deposits.

\section{STRATIGRAPHIC IMPLICATION}

Detailed analysis of the heavy mineral assemblage of the kaolin deposits in the Rio Capim area can be used first to demonstrate that, despite the apparent muddy nature of the semi-flint, these deposits consist actually of coarser-grained lithologies, which include intraformational conglomerates and, possibly, sandstones (lithic or feldspatic?), as shown by the high amount of heavy mineral recovered from these beds. The result of this 


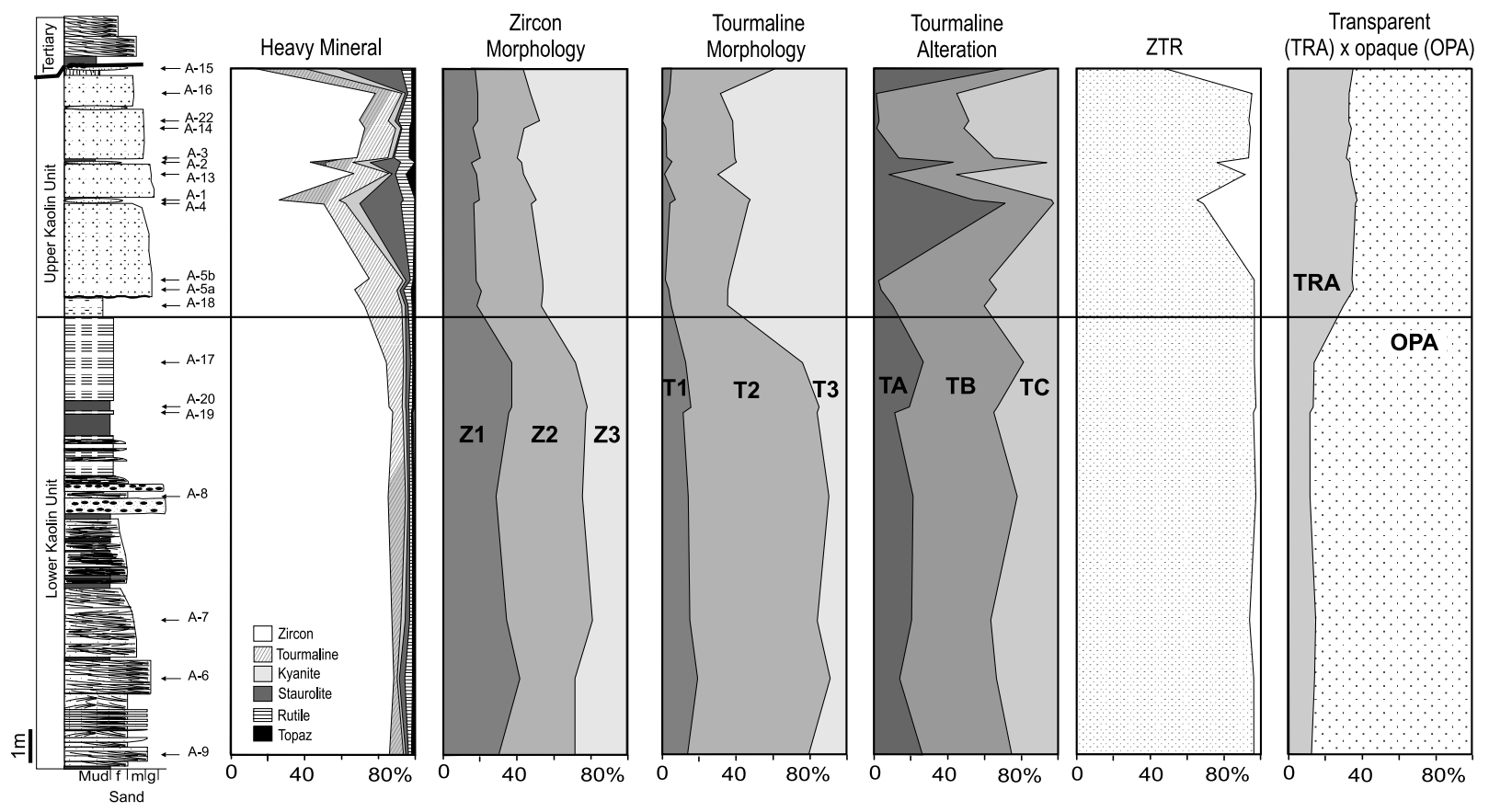

Fig. 4 - Measured lithostratigraphic profile 2 of the IRCC quarry, with frequencies of main heavy minerals and of their textures.
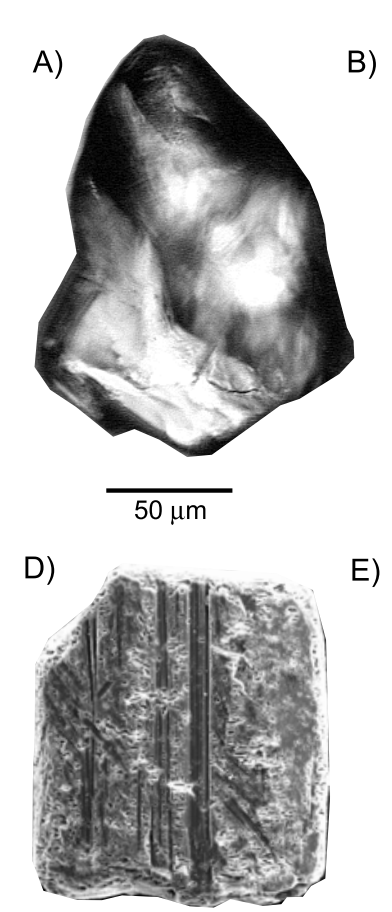

$2 \overline{25 \mathrm{~m}}$
B)

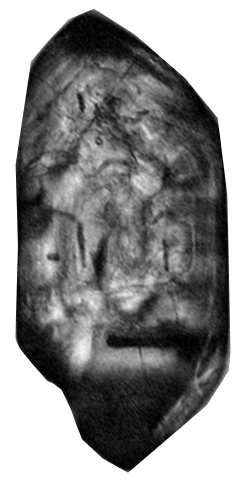

$50 \mu \mathrm{m}$

E)

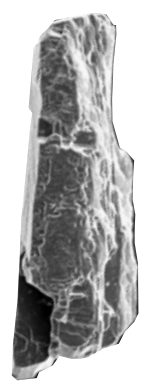

$4 \overline{0 \mu m}$
C)

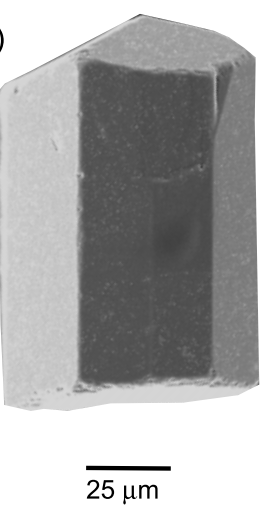

F)

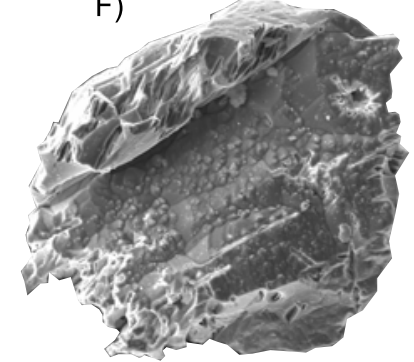

$4 \overline{4 \mu \mathrm{m}}$

Fig. 5 - Main characteristics of the heavy minerals from the lower kaolin unit, illustrating: A) anhedric angular zircon; B) euhedric zircon displaying internally growth lines; C) euhedric tourmaline; D) altered tourmaline; E) altered kyanite; and F) altered staurolite. 
A)

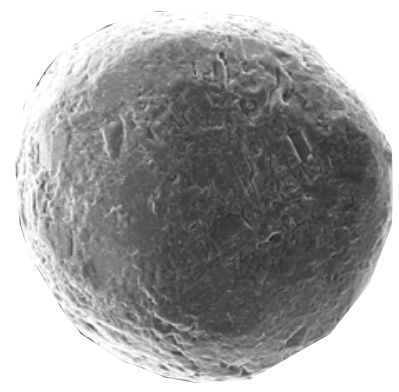

$2 \overline{20 \mathrm{~m}}$

D)

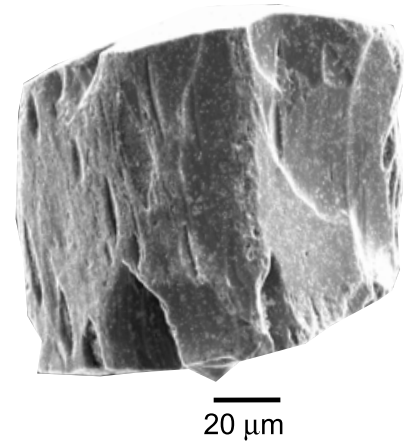

B)

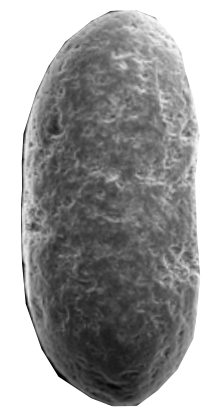

$3 \overline{0 \mathrm{~m}}$

E)

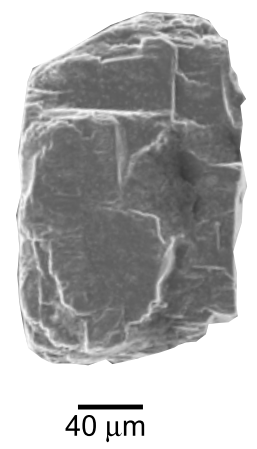

C)

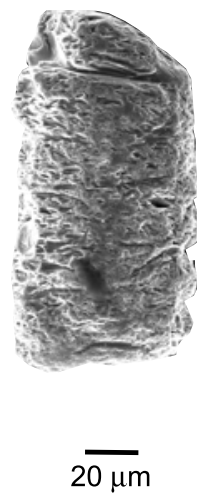

F)

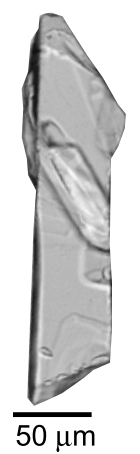

Fig. 6 - Main characteristics of the heavy minerals from the upper kaolin unit, illustrating: A) rounded zircon; B) rounded tourmaline; C) very altered tourmaline; D) partly altered staurolite; E) partly altered kyanite; and F) unaltered staurolite from the layers of quartz sandstones that occur within the semi-flint kaolin.

study also brought new independent elements that revealed to be very helpful to better define the internal stratigraphy. In general, the types of minerals do not change much throughout the whole section, being represented, as expected, by an overall mature assemblage. However, it is remarkable that each stratigraphic kaolin unit displays a particular signature, defined by differences in the proportions of the whole heavy minerals assemblage as well as of their textural characteristics.

The lower soft and upper semi-flint kaolin units can be definitely considered as distinct depositional sequences. This interpretation is provided with basis on a combination of characteristics comparing the two kaolin deposits, rather than from a single feature.

The higher proportion of transparent relative to opaque minerals in the upper kaolin unit, which reaches a volume corresponding to more than the double rela- tive to the lower unit, can be used to distinguish these deposits. In addition, despite the overall mature nature of the heavy mineral assemblage throughout the studied kaolin units, the different zircon values attest that the lower unit is mineralogically slightly more stable than the upper one.

One possibility to explain the changes in the volume of transparent minerals and increase of zircon if a same stratigraphic unit is considered would be to invoke different sources due to the influence of varying sediment influx. The sedimentary setting proposed for these units, as previously mentioned, is marine transitional, most likely fluvial to estuarine. Therefore, two sediment sources, one marine and another fluvial, were active, which could have contributed with different heavy mineral assemblages. Another possibility would be to invoke replacements and dissolutions linked to the 
post-depositional evolution as the causes for these differences in heavy mineral assemblage. In fact, some works focusing on heavy minerals have shown a tendency for increase the mineralogical maturity with depth (Pettijohn 1941, Morton 1984, Milliken 1988, Milliken and Mack 1990). However, a gradational rather than an abrupt change would be expected in both cases, which do not occur in the study area where the kaolin units are rather well defined by a discontinuity surface.

The subtle change in the volume of transparent minerals and degree of maturity is, thus, related to a change in sediment source, rather than a result of post-depositional processes. This is particularly revealed by morphological characteristics of the zircon and tourmaline grains. The much higher volumes of anhedric, rounded to sub-rounded grains of zircon and tourmaline in the upper unit (i.e., almost 50\% and 70\% respectively) lead to suggest that this includes grains that were undergone to a higher degree of reworking. Part of the sediments could have been derived from recycling of underlying kaolin deposits. This interpretation is consistent with our ongoing studies, which reveal that the lower kaolin unit would have formed by replacement of feldspars during burial, while the upper kaolin unit seems to have formed by replacement of detritic kaolin reworked from underlying deposits. However, the increased volume of unaltered transparent heavy minerals, such as staurolite, tourmaline and kyanite, in the upper kaolin unit leads to conclude that, even considering that this unit contains sediments reworked from the underlying kaolin deposits, a distinct source must be invoked.

Therefore, combination of all data from the study area can be used to discard definitely the possibility of considering the upper and lower units as resulting from a progressive downward weathering, as proposed elsewhere (Truckenbrodt et al. 1991, Kotschoubey et al. 1996, 1999, Costa and Moraes 1998). If so, a rather progressive change in mineralogical characteristics would be expected. In addition, there would have an upward decrease in the volume of altered minerals, possibly followed by an increase in opaque relative to transparent.

The distinct mineralogical characteristics of the thin layers of quartz sandstones that occur within the upper unit are attributed to changes in sedimentary influx. This assumption conforms to the attribution of these beds to lags associated with scours formed during wave (storm) reworking, as provided by facies analysis (Rossetti and Santos Jr 2006).

The present study of heavy minerals also can provide some insights to help deciphering the relationship of the intermediate unit with the two other kaolin units. As mentioned earlier in this work, this unit was probably formed by syn-sedimentary seismic activity and large-scale mass failure through debris flows and slumps (Rossetti and Santos Jr 2003). However, a question remains if this belongs to either the lower or upper kaolin unit, or even if it might record a third stratigraphic unit. The results presented herein show that the characteristics of the heavy mineral assemblage from the intermediate unit are comparable with those from the upper kaolin unit. This leads to the conclusion that the intermediate and upper units might be part of a same stratigraphic interval.

\section{PROVENANCE}

Distinct source rocks were established for the kaolin units through the study of heavy minerals and their morphogies. Although the species of heavy minerals do not change, their proportion varies substantially. Distinct source rocks of Ipixuna sandstones in the Capim region, southern border of the Cametá Basin, were established through of heavy minerals and their morphologies. The similar mineralogy in both units suggests the same type of sources but the influence of each one was different.

The association of staurolite, kyanite and andalusite indicates metamorphic rocks and the presence of topaz and monazite points igneous sources. On the other hand, the euhedric to sub-euhedric zircon and tourmaline grains, combined with the occurrence of rounded forms, suggest mixture with sediments derived from other depositional cycles. The idiomorphic grains illustrate first-cycle sediments and the rounded grains demonstrate an evident contribution from sedimentary deposits. Considering the geological framework, in association with paleoccurrent patterns (Rossetti and Santos Jr 2003, Nascimento and Góes 2005), the obvious potential sources to the sediments from the lower kaolin unit were in the eastern portion of the Amazonian Craton/Araguaia Belt and, subordinately, overall recycled sediments from the Paleozoic sedimentary rocks of Parnaíba Basin. The 
increase of rounded to sub-rounded grains in the upper kaolin unit suggests that the recycling of previous sedimentary deposits was much more important than first order sources, with sediment being derived from reworking of the lower kaolin unit, and possibly also from the Paleozoic Parnaíba Basin. However, the important presence of unaltered and angular kyanite and staurolite grains demonstrates new arrival of sediments derived from the crystalline basement. The lack of structures in this deposits which indicates palaeoccurrent do not permit deduce the potential area source.

\section{CONCLUSIONS}

Considering the foregoing discussion, the attribution of the lower and upper kaolin units to different stratigraphic units is confirmed herein. The results presented herein also show that the characteristics of the heavy mineral assemblage from the intermediate kaolin unit are comparable with those from the upper kaolin unit. This study demonstrated that, despite other more sophisticated method, heavy mineral analysis is a powerful tool for stratigraphic correlation in sequences with lack of biostratigraphic control.

The combination of all data from the study area can be used to discard definitely the possibility of considering the upper and lower kaolin units as resulting from a progressive downward weathering. These units display distinct provenances and depositional histories.

\section{ACKNOWLEDGMENTS}

This paper was financed by Conselho Nacional de Desenvolvimento Científico e Tecnológico (CNPq), projects \#474978/2001-0 and 452572/2006-1. The logistic support was provided by Universidade Federal do Pará and Museu Paraense Emílio Goeldi. Thanks are due to the Imery Rio Caulim Capim (IRCC) for the permission to access the kaolin quarries. The authors also acknowledge the geologist Sá Pereira for the companionship and many discussions in the field.

\section{RESUMO}

Estudos de minerais pesados provenientes em depósitos cauliníticos da Formação Ipixuna na região do rio Capim (Brasil) revelaram uma mineralogia matura a supermatura, representada dominantemente por zircão e turmalina e, subordinada- mente, rutilo, cianita e estaurolita. Os minerais encontrados não variam muito, entretanto cada unidade caulinítica apresenta uma assinatura particular definida por diferenças nas proporções entre os principais minerais, assim como em suas características texturais. Este trabalho demonstrou que as unidades de caulim soft (inferior) e semi-flint (superior) podem ser consideradas seqüências deposicionais distintas. As altas percentagens de opacos em relação aos minerais transparentes e altos teores de zircão são diagnósticos da unidade caulinítica inferior. O incremento no volume de grãos de zircão e turmalina arredondados a subarredondados na unidade caulinítica superior sugere que esta inclui grãos que foram submetidos a um grau mais elevado de retrabalhamento. $\mathrm{O}$ aumento no volume de grãos não alterados de estaurolita e cianita na unidade superior leva a concluir que, além da reciclagem sedimentar, uma fonte distinta deve ser invocada. Estes resultados também mostram que as características da assembléia de minerais pesados da unidade intermediária são comparáveis com aqueles da unidade superior, o que sugere mesmo posicionamento estratigráfico.

Palavras-chave: minerais pesados, depósitos cauliníticos, Formação Ipixuna, Neocretáceo, Sub-bacia de Cametá.

\section{REFERENCES}

BRANDÃo JASL AND FeiJó FJ. 1994. Bacia da Foz do Amazonas. Bol Geocienc Petrobras 8: 91-99.

Costa JBS, Hasui Y, Bermeguy R and Villegas J. 2002. Tectonics and paleogeography of the Marajó Basin, northern Brazil. An Acad Bras Cienc 74: 519-531.

Costa ML and Moraes EL. 1998. Mineralogy, geochemistry and genesis of kaolin from the Amazon region. Mineralium Deposita 33: 283-297.

Hermann W and PolozeK K. 1999. The heavy mineral record in the Pliocene to Quaternary sediments of the CIROS-2 drill core, McMurdo Sound, Antarctica. Sed Geol 128: 223-244.

HUBERT JE. 1962. A zircon-tourmaline-rutile maturity index and the interdependence of the composition of heavy mineral assemblages with the cross composition and texture of sandstones. J Sediment Petrol 32: 440-450.

Kotschoubey B, Trukenbrodt W and Hieronymus B. 1996. Depósitos de caulim e argila "semi-flint" no noroeste do Pará. Rev Bras Geoc 26: 71-80.

Kotschoubey B, Duarte ALS and Truckenbrodt W. 1999. Cobertura bauxitica e origem do caulim do Morro 
do Felipe, Baixo Rio Jari, Estado do Amapá. Rev Bras Geoc 29: 443-450.

Mahaney WC. 2002. Atlas of sand grain surface textures and applications. New York: Oxford University Press, $237 \mathrm{p}$.

MANGE MA AND MAURER HFW. 1992. Heavy mineral in colour. London: Chapman \& Hall, 147 p.

Mange MA, Dewey JF And Wright DT. 2003. Heavy minerals solve structural and stratigraphic problems in Ordovician strata of the western Irish Caledonides. Geol Mag 140: 25-30.

MANGE-RAJETZKY MA. 1995. Subdivision and correlation of monotonous sandstone sequences using high resolution heavy mineral analysis, a case study: the Triassic of Central Graben. In: DunAY RE AND HaILwood EA (Eds), Non-biostratigraphical methods of dating and correlation. Geol Soc Spec Publ 89: 23-30.

Milani EJ And Thomaz Filho A. 2000. Sedimentary basins of South America. In: CORDANI UG, Milani EJ, Thomaz Filho A and Campos DA (Eds), $31^{\text {st }}$ International Geological Congress, Rio de Janeiro, RJ, Tectonic evolution of South America, p. 389-452.

MiLLIKEN KL. 1988. Loss of provenance information through subsurface diagenesis in Plio-Pleistocene sandstones, northern Gulf of Mexico. J Sediment Petrol 58: 992-1002.

Milliken KL AND Mack LE. 1990. Subsurface dissolution of heavy minerals, Frio Formation sandstones to the ancestral Rio Grande Province, South Texas. Sed Geol 68: 187-199.

Morton AC. 1984. Stability of detrital heavy minerals in Tertiary sandstones of the North Sea Basin provenance studies. Clay Miner 19: 287-308.

MorTON AC. 1985. Heavy minerals in provenance studies. In: ZuFFA GG (Ed), Provenance of arenites, Dordrecht: Reidel, p. 249-277.

Morton AC. 1991. Geochemical studies of detrital heavy minerals and their application to provenance research. In: Morton AC, TOdD SP AND HaUghton PDW (Eds), Developments in Sedimentary Provenance Studies. Geol Soc London, Spec Publ 57: 31-45.

Morton AC AND GRANT S. 1998. Cretaceous depositional systems in the Norwegian Sea: heavy minerals constraints. Am Assoc Petrol Geol Bull 82: 274-290.

Morton AC And Hallsworth C. 1999. Processes controlling the composition of heavy mineral assemblages in sandstones. Sed Geol 124: 3-29.
Morton AC And Hurst A. 1995. Correlation of sandstones using heavy minerals: an example from the Statfjord Formation of the Snorre Field, northern North Sea. In: Dunay RE AND HaIlwood EA (Eds), Non-biostratigraphical methods of dating and correlation. Geol Soc London, Spec Publ 89: 3-22.

Morton AC, Claoué-Long JC and Berge C. 1996. SHRIMP constraints on sediment provenance and transport history in the Mesozoic Stafjord Formation, North Sea. J Geol Soc 153: 915-929.

NAscimento MS AND GóES AM. 2005. Distribuição estratigráfica e proveniência de minerais pesados das formações Ipixuna e Barreiras, região do rio Capim, sul da Sub-bacia de Cametá. Rev Bras Geoc 35: 49-58.

Pettijohn FJ. 1941. Persistence of heavy minerals and geologic age. J Geol 49: 612-625.

Rossetti DF. 2004. Paleosurfaces from Northeastern Amazonia as a key for reconstructing paleolandscapes and understanding weathering products. Sed Geol 169: 151-174.

Rossetti DF And Santos JR AEA. 2003. Events of sediment deformation and mass failure in Upper Cretaceous Estuarine Deposits (Cametá Basin, Northern Brazil) as evidence for seismic activity. Sed Geol 169: 107-130.

Rossetti DF AND SANtos JR AEA. 2006. Analysing the origin of the Upper Cretaceous-?Lower Tertiary Rio Capim semi flint (Pará State, Brazil) under a sedimentologic perspective. Sed Geol 186: 133-144.

Rossetti DF, Truckenbrodt W And Góes AM. 1989. Estudo paleoambiental e estratigráfico dos sedimentos Barreiras e Pós-Barreiras na região bragantina, NE do Estado do Pará. Bol Mus Paraense Emílio Goeldi, Sér Cienc Terra 1: 25-37.

SAntos JR AEA AND Rossetti DF. 2003. Paleoambiente e estratigrafia da Formação Ipixuna, área do rio Capim, leste da Sub-bacia de Cametá. Rev Bras Geoc 33: 313-324.

SMALER D AND LAIRD MG. 1995. Relation of heavy mineral populations to stratigraphy of Cretaceous formations in Marlborough, New Zealand. New Zealand, J Geol Geophys 38: 211-222.

SVEndSEn JB AND HaRTLEY NR. 2002. Synthetic heavy mineral stratigraphy: applications and limitations. Mar Petrol Geol 19: 389-405.

Sousa DC, Vital H AND Fonseca VP. 2000. Stratigraphic significance of heavy minerals in sediments of northeastern Brazil. Rev Bras Geoc 30: 470-473. 
Truckenbrodt W, Kotschoubey B AND SchellmanN W. 1991. Composition and origin of the clay cover on North Brazilian laterites. Geologische Rundschau 80: 591-610.

Truckenbrodt W, NASCIMEnto MS AND GóEs AM. 2005. Distribuição de minerais pesados em arenitos das formações fanerozóicas no nordeste do Pará e noroeste do Maranhão. In: Horbe AMC AND SouzA VS (Coords), Contribuições à Geologia da Amazônica. Universidade Federal do Amazonas, Manaus, AM, Brasil, p. $181-189$.
Weissbrod T AND NAChMias J. 1986. Stratigraphic significance of heavy minerals in the late PrecambrianMesozoic clastic sequence ("Nubian Sandstone") in the near east. Sed Geol 47: 263-291. 